\title{
Biodegradation: Involved Microorganisms and Genetically Engineered Microorganisms
}

\author{
Nezha Tahri Joutey, Wifak Bahafid, \\ Hanane Sayel and Naïma El Ghachtouli \\ Additional information is available at the end of the chapter \\ http://dx.doi.org/10.5772/56194
}

\section{Introduction}

Biodegradation is defined as the biologically catalyzed reduction in complexity of chemical compounds [1]. Indeed, biodegradation is the process by which organic substances are broken down into smaller compounds by living microbial organisms [2]. When biodegradation is complete, the process is called "mineralization". However, in most cases the term biodegradation is generally used to describe almost any biologically mediated change in a substrate [3].

So, understanding the process of biodegradation requires an understanding of the microorganisms that make the process work. The microbial organisms transform the substance through metabolic or enzymatic processes. It is based on two processes: growth and cometabolism. In growth, an organic pollutant is used as sole source of carbon and energy. This process results in a complete degradation (mineralization) of organic pollutants. Cometabolism is defined as the metabolism of an organic compound in the presence of a growth substrate that is used as the primary carbon and energy source [4]. Several microorganisms, including fungi, bacteria and yeasts are involved in biodegradation process. Algae and protozoa reports are scanty regarding their involvement in biodegradation [5]. Biodegradation processes vary greatly, but frequently the final product of the degradation is carbon dioxide [6]. Organic material can be degraded aerobically, with oxygen, or anaerobically, without oxygen [4, 7].

Biodegradable matter is generally organic material such as plant and animal matter and other substances originating from living organisms, or artificial materials that are similar enough to plant and animal matter to be put to use by microorganisms. Some microorganisms have the astonishing, naturally occurring, microbial catabolic diversity to degrade, transform or accumulate a huge range of compounds including hydrocarbons (e.g. oil), 
polychlorinated biphenyls (PCBs), polyaromatic hydrocarbons (PAHs), radionuclides and metals [8].

The term biodegradation is often used in relation to ecology, waste management and mostly associated with environmental remediation (bioremediation) [2]. Bioremediation process can be divided into three phases or levels. First, through natural attenuation, contaminants are reduced by native microorganisms without any human augmentation. Second, biostimulation is employed where nutrients and oxygen are applied to the systems to improve their effectiveness and to accelerate biodegradation. Finally, during bioaugmentation, microorganisms are added to the systems. These supplemental organisms should be more efficient than native flora to degrade the target contaminant [9]. A feasible remedial technology requires microorganisms being capable of quick adaptation and efficient uses of pollutants of interest in a particular case in a reasonable period of time [10]. Many factors influence microorganisms to use pollutants as substrates or cometabolize them, like, the genetic potential and certain environmental factors such as temperature, $\mathrm{pH}$, and available nitrogen and phosphorus sources, then, seem to determine the rate and the extent of degradation [4]. Therefore, applications of genetically engineered microorganisms (GEM) in bioremediation have received a great deal of attention. These GEM have higher degradative capacity and have been demonstrated successfully for the degradation of various pollutants under defined conditions. However, ecological and environmental concerns and regulatory constraints are major obstacles for testing GEM in the field [11].

In this chapter we will try to foster an in-depth understanding of biodegradation process by trying to cover all types of microorganisms implied in degradation of different pollutants. Moreover, although we are aware that the term biodegradation is often used in relation to ecology, waste management, biomedicine, and the natural environment (bioremediation) and is now commonly associated with environmentally friendly products, this chapter will mainly give attention to biodegradation in relation to bioremediation through describing processes (natural attenuation, biostimulation and bioaugmentation) utilizing degradation abilities of microorganisms in bioremediation and factors affecting this process. Microorganisms may be genetically engineered for many purposes. One such purpose is for the efficient degradation of pollutants. So, the second scope of this chapter is to demonstrate the importance of some GEM in this process and to describe obstacles for testing GEM in the field, which must be overcome before GEM can provide an effective clean-up process at lower cost. Figure 1 summarizes the contents of this chapter.

\section{Role of microorganisms in biodegradation of pollutants}

In this chapter, biodegradation is described associated with environmental bioremediation. Therefore, biodegradation is nature's way of recycling wastes, or breaking down organic matter into nutrients that can be used and reused by other organisms. In the microbiological sense, "biodegradation" means that the decaying of all organic materials is carried out by a 


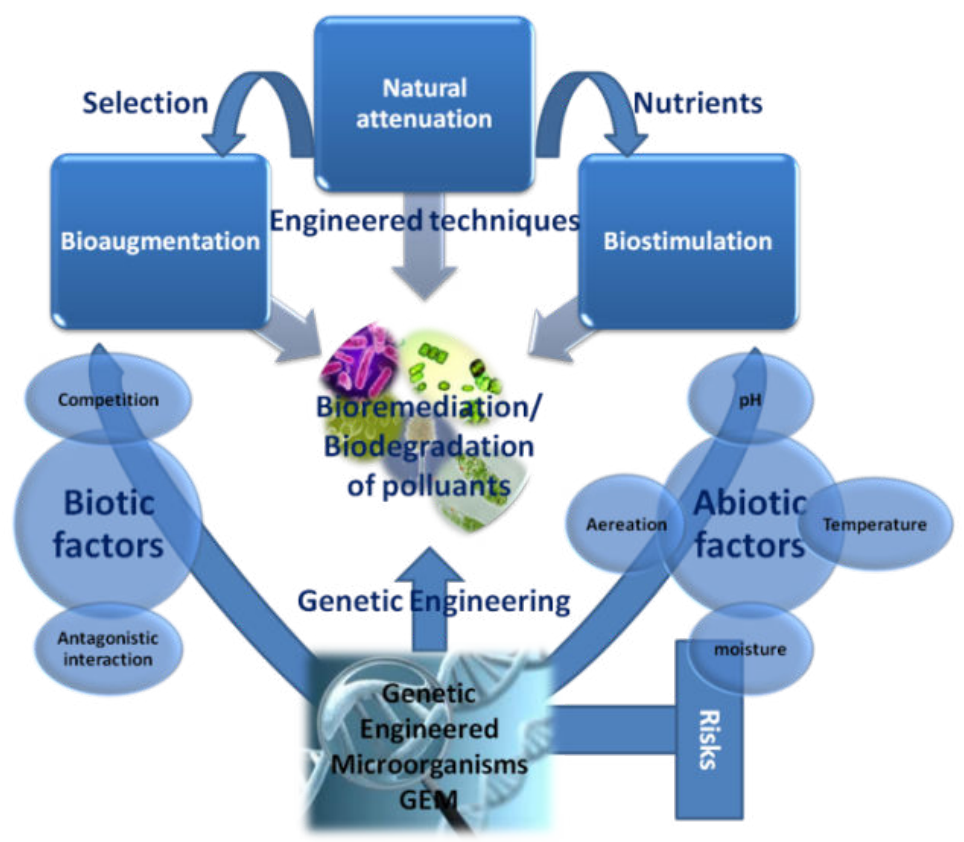

Figure 1. Bioremediation of polluants utilizing biodegradation abilities of microorganisms include the natural attenuation, although it may be enhanced by engineered techniques, either by addition of selected microorganisms (bioaugmentation) or by biostimulation, where nutrients are added. Genetic engineering is also used to improve the biodegradation capabilities of microorganisms by GEM. Nevertheless, there are many factors affecting the efficiency of this process and risks associated to the use of GEM in the field.

huge assortment of life forms comprising mainly bacteria, yeast and fungi, and possibly other organisms.

Bioremediation and biotransformation methods endeavour to harness the astonishing, naturally occurring, microbial catabolic diversity to degrade, transform or accumulate a huge range of compounds including hydrocarbons (e.g. oil), polychlorinated biphenyls (PCBs), polyaromatic hydrocarbons (PAHs), radionuclides and metals [12].

\subsection{Some biodegradable pollutants}

In the last few decades, highly toxic organic compounds have been synthesized and released into the environment for direct or indirect application over a long period of time. Fuels, polychlorinated biphenyls (PCBs), polycyclic aromatic hydrocarbons (PAHs), pesticides and dyes are some of these types of compounds [9]. Some other synthetic chemicals like radionuclides and metals are extremely resistant to biodegradation by native flora compared with the naturally occurring organic compounds that are readily degraded upon introduction into the environment. 
Hydrocarbons: are organic compounds whose structures consist of hydrogen and carbon. Hydrocarbons can be seen as linear linked, branched or cyclic molecules. They are observed as aromatic or aliphatic hydrocarbons. The first one has benzene $\left(\mathrm{C}_{6} \mathrm{H}_{6}\right)$ in its structure, while the aliphatic one is seen in three forms: alkanes, alkenes and alkynes [13].

Polycyclic aromatic hydrocarbons (PAHs): are important pollutants class of hydrophobic organic contaminants (HOCs) widely found in air, soil and sediments. The major source of PAH pollution is industrial production [7]. They have been studied with increasing interest for more than twenty years because of more findings about their toxicity, environmental persistence and prevalence [14]. PAHs can sorb to organic-rich soils and sediments, accumulate in fish and other aquatic organisms, and may be transferred to humans through seafood consumption [7]. The biodegradation of PAHs can be considered on one hand to be part of the normal processes of the carbon cycle, and on the other as the removal of man-made pollutants from the environment. The use of microorganisms for bioremediation of PAH-contaminated environments seems to be an attractive technology for restoration of polluted sites.

Polychlorinated biphenyls (PCBs): are mixtures of synthetic organic chemicals. Due to their non-flammability, chemical stability, high boiling point, and electrical insulating properties, PCBs were used in hundreds of industrial and commercial applications including electrical, heat transfer, and hydraulic equipment; as plasticizers in paints, plastics, and rubber products; in pigments, dyes, and carbonless copy paper; and many other industrial applications. Consequently, PCBs are toxic compounds that could act as endocrine disrupters and cause cancer. Therefore, environmental pollution with PCBs is of increasing concern [15].

Pesticides: are substances or mixture of substances intended for preventing, destroying, repelling or mitigating any pest. Pesticides which are rapidly degraded are called nonpersistent while those which resist degradation are termed persistent. The most common type of degradation is carried out in the soil by microorganisms, especially fungi and bacteria that use pesticides as food source [16].

Dyes: are widely used in the textile, rubber product, paper, printing, color photography, pharmaceuticals, cosetics and many other industries [17]. Azo dyes, which are aromatic compounds with one or more $(-\mathrm{N}=\mathrm{N}-)$ groups, are the most important and largest class of synthetic dyes used in commercial applications [18]. These dyes are poorly biodegrabale because of their structures and treatment of wastewater containing dyes usually involves physical and / or chemical methods such as adsorption, coagulation-flocculation, oxidation, filtration and electrochemical methods [19].

The success of a biological process for color removal from a given effluent depends in part on the utilization of microorganisms that effectively decolorize synthetic dyes of different chemical structures.

Radionuclides: a radionuclide is an atom with an unstable nucleus, characterized by excess energy available to be imparted either to a newly created radiation particle within the nucleus or via internal conversion. During this process, the radionuclide is said to undergo radioactive decay, resulting in the emission of gamma ray(s) and/or subatomic particles such as alpha or beta particles [20]. 
Heavy metals: unlike organic contaminants, the metals cannot be destroyed, but must either be converted to a stable form or removed. Bioremediation of metals is achieved through biotransformation. Mechanisms by which microorganisms act on heavy metals include biosorption (metal sorption to cell surface by physicochemical mechanisms), bioleaching (heavy metal mobilization through the excretion of organic acids or methylation reactions), biomineralization (heavy metal immobilization through the formation of insoluble sulfides or polymeric complexes), intracellular accumulation, and enzyme-catalyzed transformation (redox reactions) [21]. The major microbial processes that influence the bioremediation of metals are summarized in Figure 2.

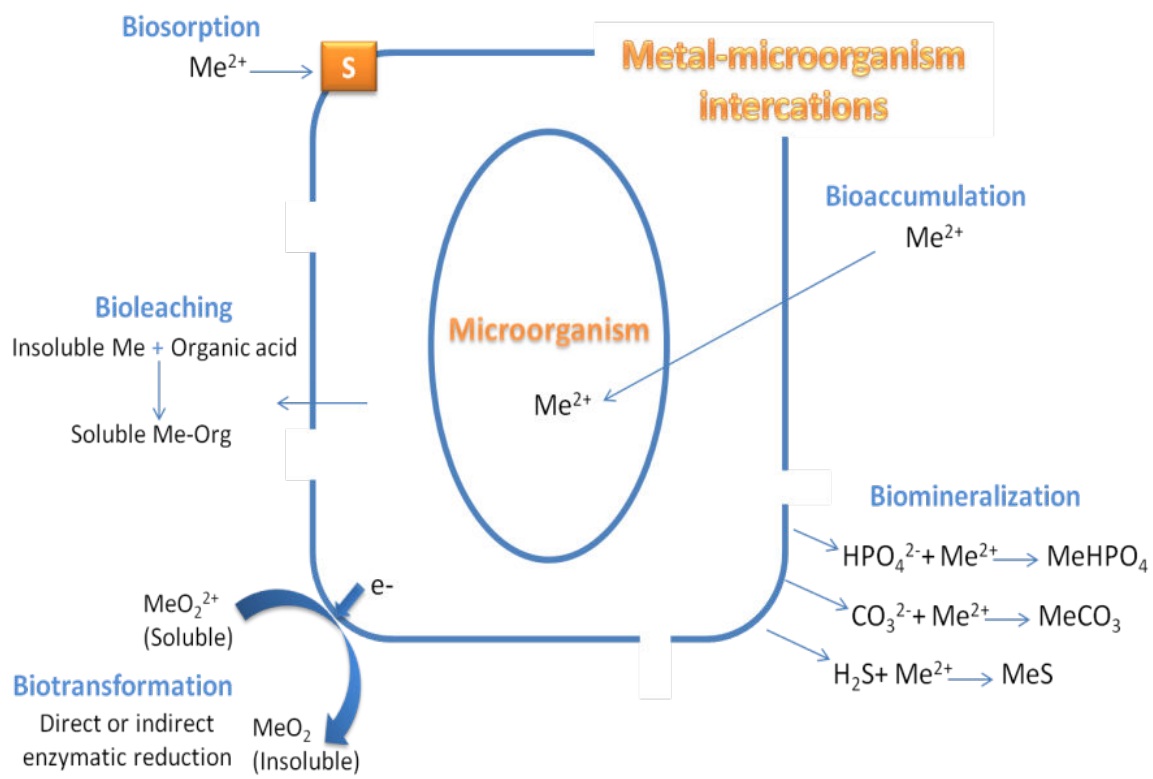

Figure 2. Microbial processes used in bioremediation technologies modified from Lloyd and Lovley [21].

\subsection{Bacterial degradation}

There are many reports on the degradation of environmental pollutants by different bacteria. Several bacteria are even known to feed exclusively on hydrocarbons [22]. Bacteria with the ability to degrade hydrocarbons are named hydrocarbon-degrading bacteria. Biodegradation of hydrocarbons can occur under aerobic and anaerobic conditions, it is the case for the nitrate reducing bacterial strains Pseudomonas sp. and Brevibacillus sp. isolated from petroleum contaminated soil [23]. However, data presented by Wiedemeier et al. [24] suggest that the anaerobic biodegradation may be much more important. 25 genera of hydrocarbon degrading bacteria were isolated from marine environment [25]. Furthermore, among 80 bacterial strains 
isolated by Kafilzadeh et al. [26] which belonged to 10 genus as follows: Bacillus, Corynebacterium, Staphylococcus, Streptococcus, Shigella, Alcaligenes, Acinetobacter, Escherichia, Klebsiella and Enterobacter, Bacillus was the best hydrocarbon degrading bacteria.

Bacterial strains that are able to degrade aromatic hydrocarbons have been repeatedly isolated, mainly from soil. These are usually gram negative bacteria, most of them belong to the genus Pseudomonas. The biodegradative pathways have also been reported in bacteria from the genera Mycobacterium, Corynebacterium, Aeromonas, Rhodococcus and Bacillus [7].

Although many bacteria are able to metabolize organic pollutants, a single bacterium does not possess the enzymatic capability to degrade all or even most of the organic compounds in a polluted soil. Mixed microbial communities have the most powerful biodegradative potential because the genetic information of more than one organism is necessary to degrade the complex mixtures of organic compounds present in contaminated areas [27].

Both, anaerobic and aerobic bacteria are capable of biotransforming PCBs. Higher chlorinated PCBs are subjected to reductive dehalogenation by anaerobic microorganisms. Lower chlorinated biphenyls are oxidized by aerobic bacteria [28]. Research on aerobic bacteria isolated so far has mainly focused on Gram-negative strains belonging to the genera Pseudomonas, Burkholderia, Ralstonia, Achromobacter, Sphingomonas and Comamonas. However, several reports about PCB-degrading activity and characterization of the genes that are involved in PCB degradation indicated PCB-degrading potential of some Gram-positive strains as well (genera Rhodococcus, Janibacter, Bacillus, Paenibacillus and Microbacterium) [29]. Aerobic catabolic pathway for PCB degradation seems to be very similar for most of the bacteria and comprises four steps catalysed by the enzymes, biphenyl dioxygenase (BphA), dihydrodiol dehydrogenase (BphB), 2, 3-dihydroxybihenyl dioxygenase (DHBD) (BphC) and hydrolase $(\mathrm{BphD})$ [30].

Successful removal of pesticides by the addition of bacteria had been reported earlier for many compounds, including atrazine [31]. Recent findings concerning pesticide degrading bacteria include the chlorpyrifos degrading bacterium Providencia stuartii isolated from agricultural soil [32] and isolates Bacillus, Staphylococcus and Stenotrophomonas from cultivated and uncultivated soil able to degrade dichlorodiphenyltrichloroethane (DDT) [33].

Researches on bacterial strains that are able to degrade azo dyes under aerobic and anaerobic conditions have been extensively reported [34]. Based on the available literature, it can be concluded that the microbial decolourization of azo dyes is more effective under anaerobic conditions. On the other hand, these conditions lead to aromatic amine formation, and these are mutagenic and toxic to humans requiring a subsequent oxidative (aerobic) stage for their degradation. In this context, the combined anaerobic/aerobic biological treatments of textile dye effluents using microbial consortia are common in the literature [35]. For exemple, Chaube et al. [36] have used the mix consortia of bacteria consisting of Proteus sp., Pseudomonas sp. and Enterococcus sp. in biodegradation and decolorisation of dye. However, several researchers have identified single bacterial strains that have very high efficacy for removal of azo dyes, it is the case of Shewanella decolorations [37]. In contrast to mixed cultures, the use of a pure culture has several advantages. These include predictable performance and detailed knowledge on 
the degradation pathways with improved assurance that catabolism of the dyes will lead to nontoxic end products under a given set of environmental conditions. Another advantage is that the bacterial strains and their activity can be monitored using culture-based or molecular methods to quantify population densities of the bacteria over time. Knowledge of the population density can be extrapolated to quantitative analysis of the kinetics of azo dye decoloration and mineralization [38].

Heavy metals cannot be destroyed biologically (no"degradation", change in the nuclear structure of the element, occurs) but are only transformed from one oxidation state or organic complex to another [39]. Besides, bacteria are also efficient in heavy metals bioremediation. Microorganisms have developed the capabilities to protect themselves from heavy metal toxicity by various mechanisms, such as adsorption, uptake, methylation, oxidation and reduction. Reduction of metals can occur through dissimilatory metal reduction [40], where bacteria utilize metals as terminal electron acceptors for anaerobic respiration. In addition, bacteria may possess reduction mechanisms that are not coupled to respiration, but instead are thought to impart metal resistance. For example, reduction of $\mathrm{Cr}(\mathrm{VI})$ to $\mathrm{Cr}(\mathrm{III})$ under aerobic [41] or anaerobic conditions [42], reduction of Se(VI) to elemental Se [43], reduction of $\mathrm{U}(\mathrm{VI})$ to $\mathrm{U}(\mathrm{IV})$ [44] and reduction of $\mathrm{Hg}(\mathrm{II})$ to $\mathrm{Hg}(0)$ [45]. Microbial methylation plays an important role in heavy metals bioremediation, because methylated compounds are frequently volatile. For example, Mercury, $\mathrm{Hg}$ (II) can be biomethylated by a number of different bacterial species Alcaligenes faecalis, Bacillus pumilus, Bacillus sp., P. aeruginosa and Brevibacterium iodinium to gaseous methyl mercury [46]. In addition to redox conversions and methylation reactions, acidophilic iron bacteria like Acidithiobacillus ferrooxidans [47] and sulfur oxidizing bacteria [48] are able to leach high concentrations of $\mathrm{As}, \mathrm{Cd}, \mathrm{Cu}, \mathrm{Co}$ and $\mathrm{Zn}$ from contaminated soils. On the other hand metals can be precipitated as insoluble sulfides indirectly by the metabolic activity of sulphate reducing bacteria [48]. Sulphate reducing bacteria are anaerobic heterotrophs utilizing a range of organic substrates with $\mathrm{SO}_{4}{ }^{2-}$ as the terminal electron acceptor. Heavy metal ions can be entrapped in the cellular structure and subsequently biosorbed onto the binding sites present in the cellular structure. This method of uptake is independent of the biological metabolic cycle and is known as biosorption or passive uptake. The heavy metal can also pass into the cell across the cell membrane through the cell metabolic cycle. This mode of metal uptake is referred as active uptake. Pseudomonas strain, characterized as part of a project to develop a biosorbent for removal of toxic radionuclides from nuclear waste streams, was a potent accumulator of uranium (VI) and thorium (IV) [49].

Most works on pollutants bioremediation uses pure microbial cultures. However, the use of mixed microbial cultures is undoubtedly advantageous. Some of the best examples of enrichment cultures comprising several specific consortia involve the bioremediation. In the case of heavy metals removal, Adarsh et al. [50] have used an environmental bacterial consortium to remove $\mathrm{Cd}, \mathrm{Cr}, \mathrm{Cu}, \mathrm{Ni}$ and $\mathrm{Pb}$ from a synthetic wastewater effluent. For $\mathrm{Cr}(\mathrm{VI})$ removal we reported that the survival and stability of bacteria are better when they are present as a mixed culture, especially, in highly contaminated areas and in the presence of more than one type of metal [51]. Indeed, the indigenous bacteria enriched from chromium contaminated biotopes, were able to remove $\mathrm{Cr}(\mathrm{VI})$ successfully in multi-contaminated heavy metal solution [51]. A 
microbial consortium consisting of three bacterial Pseudomonas species originally obtained from dye contaminated sites was capable of decolorizing textile effluent and dye faster than the individual bacteria under static conditions [52].

\subsection{PGPR and PGPB degradation}

Plant associated bacteria, such as endophytic bacteria (non-pathogenic bacteria that occur naturally in plants) and rhizospheric bacteria (bacteria that live on and near the roots of plants), have been shown to contribute to biodegradation of toxic organic compounds in contaminated soil and could have potential for improving phytoremediation [53]. Plant growth promoting rhizobacteria (PGPR) are naturally occurring soil bacteria that aggressively colonize plant roots and benefit plants by providing growth promotion [54]. Some plants can release structural analogs of PAHs such as phenols, to promote the growth of hydrocarbon degrading microbes and their degradation on PAHs. For such plant/microbe systems, an important class of bacteria is Pseudomonas spp., have PGPR activity and hydrocarbon degrading capacity [55]. Furthermore, the rhizosphere of vegetation in contaminated field contains higher diversity of population of PAH-degrading bacteria, among which two Lysini bacillus strains were isolated [56]. Culturable PCB degraders were also associated with both the rhizosphere and root zone of mature trees growing naturally in a contaminated site, they were identified as members of the genus Rhodococcus, Luteibacter and Williamsia, which suggest that biostimulation through rhizoremediation is a promising strategy for enhancing PCB degradation in situ [57]. Also, the free living nitrogen fixer Azospirillum lipoferum generally found in the rhizoplane of the crop plants was used for Malathion degradation which is one of the largest organo phosphorus insecticides in the world [33]. Results from the literature suggest that heavy metals may be removed from contaminated soils using plant growth promoting rhizobacteria. The use of soil bacteria (often plant growth promoting bacteria (PGPB)) as adjuncts in metal phytoremediation can significantly facilitate the growth of plants in the presence of high (and otherwise inhibitory) levels of metals [58]. To increase the efficiency of contaminants extraction, it is interesting to apply plants combined to some microorganisms; such technique is called rhizoremediation [59].

\subsection{Microfungi and mycorrhiza degradation}

Microfungi are described as a group of organisms that constitute an extremely important and interesting group of eukaryotic, aerobic microbes ranging from the unicellular yeasts to the extensively mycelial molds [60]. Yeasts preferentially grow as single cells or form pseudomycelia, whereas molds typically grow as mycelia-forming real hyphae.

Fungi are an important part of degrading microbiota because, like bacteria, they metabolize dissolved organic matter; they are principal organisms responsible for the decomposition of carbon in the biosphere. But, fungi, unlike bacteria, can grow in low moisture areas and in low $\mathrm{pH}$ solutions, which aids them in the breakdown of organic matter [61]. Equipped with extracellular multienzyme complexes, fungi are most efficient, especially in breaking down the natural polymeric compounds. By means of their hyphal systems they are also able to colonize and penetrate substrates rapidly and to transport and redistribute nutrients within 
their mycelium [62]. Mycorrhiza is a symbiotic association between a fungus and the roots of a vascular plant. In a mycorrhizal association, the fungus colonizes the host plant's roots, either intracellularly as in arbuscular mycorrhizal fungi (AMF), or extracellularly as in ectomycorrhizal fungi. They are also an important component of soil life and soil chemistry. Bioremediation using mycorrhiza is named mycorrhizoremediation [63]. Fungi possess important degradative capabilities that have implications for the recycling of recalcitrant polymers (e.g., lignin) and for the elimination of hazardous wastes from the environment [27]. Below, some aspects of the microfungal degradation of some pollutants by unicellular and filamentous fungi are discussed.

\subsubsection{Yeasts degradation}

Several yeasts may utilize aromatic compounds as growth substrates, but more important is their ability to convert aromatic substances cometabolically. Some species such as the soil yeast Trichosporon cutaneum possess specific energy-dependent uptake systems for aromatic substrates (e.g., for phenol) [64].

Furthermore, biodegradation of aliphatic hydrocarbons occurring in crude oil and petroleum products has been investigated well, especially for yeasts. The n-alkanes are the most widely and readily utilized hydrocarbons, with those between $C_{10}$ and $C_{20}$ being most suitable as substrates for microfungi [65]. However, the biodegradation of n-alkanes having chain lengths up to $\mathrm{n}-\mathrm{C}_{24}$ has also been demonstrated [27]. Typical representatives of alkane-utilizing yeasts include Candida lipolytica, C. tropicalis, Rhodoturularubra, and Aureobasidion(Trichosporon) pullulans. Rhodotorula aurantiaca and C. ernobii were found able to degrade diesel oil [66]. Yeasts are also reported for aniline biodegradation (a potential degradation product of the azo dye breakdown) it is the example of C. methanosorbosa BP-6 [67]. According to many authors, bacteria have been described as being more efficient hydrocarbon degraders than yeast, or at least that bacteria are more commonly used as a test microorganism. However, there is information that yeasts are better hydrocarbon degraders than bacteria [68].

In addition to aromatic and aliphatic hydrocarbons compounds, microfungi may transform numerous of other aromatic organopollutants cometabolically, including polycyclic aromatic hydrocarbons (PAHs) and biphenyls, dibenzofurans, nitro aromatics, various pesticides, and plasticizers [69]. There have also been studies of PCB metabolism by yeasts C. boidinii and C. lipolytica [70] and Saccharomyces cerevisiae [71]. Insecticides and fungicides can also be adsorbed by S. cerevisiae during aerobic fermentation [72].

Yeasts are known for playing an important role in the removal of toxic heavy metals. There are many reports on biosorption of heavy metals by yeasts. Several investigations demonstrated that yeasts are capable of accumulating heavy metals such as $\mathrm{Cu}(\mathrm{II}), \mathrm{Ni}(\mathrm{II}), \mathrm{Co}(\mathrm{II}), \mathrm{Cd}(\mathrm{II})$ and $\mathrm{Mg}(\mathrm{II})$ and are superior metal accumulators compared to certain bacteria [73]. In the case of hexavalent chromium $(\mathrm{Cr}(\mathrm{VI}))$ we found that $P$. anomala is able to remove $\mathrm{Cr}(\mathrm{VI})[74]$ and we studied the biosorption of $\mathrm{Cr}(\mathrm{VI})$ by live and dead cells of three yeasts species: Cyberlindnera fabianii, Wickerhamomyces anomalus and C. tropicalis [75]. Several yeast strains S. cerevisiae, P. guilliermondii, Rhodotorula pilimanae, Yarrowiali polytica and Hansenula polymorpha have been reported to reduce $\mathrm{Cr}(\mathrm{VI})$ to $\mathrm{Cr}(\mathrm{III})$ [76]. In addition, the tolerance of $P$. guilliermondii to 
chromate was found to depend on its capacity for extracellular reduction of $\mathrm{Cr}(\mathrm{VI})$ and $\mathrm{Cr}(\mathrm{III})$ chelation [77]. Most studies, have reported the efficiency of immobilized cells of yeasts in metals removal, one example is Schizosaccharomyces pombe for copper removal [78].

\subsubsection{Filamentous fungi degradation}

The attributes that distinguish filamentous fungi from other life forms determine why they are good biodegraders. First, the mycelial growth habit gives a competitive advantage over single cells such as bacteria and yeasts, especially with respect to the colonization of insoluble substrates. Fungi can rapidly ramify through substrates, literally digesting their way along by secreting a battery of extracellular degradative enzymes. Hyphal penetration provides a mechanical adjunct to the chemical breakdown affected by the secreted enzymes. The high surface to cell ratio characteristic of filaments maximizes both mechanical and enzymatic contact with the environment. Second, the extracellular nature of the degradative enzymes enables fungi to tolerate higher concentrations of toxic chemicals than would be possible if these compounds had to be brought into the cell. In addition, insoluble compounds that cannot cross a cell membrane are susceptible to attack [3].

Many workers divide bioremediation strategies into three general categories: 1) the target compound is used as a carbon source; 2) the target compound is enzymatically attacked but is not used as a carbon source (cometabolism) and 3) the target compound is not metabolized at all but is taken up and concentrated within the organism (bioaccumulation). Although fungi participate in all three strategies, they are often more proficient at cometabolism and bioaccumulation than at using xenobiotics as sole carbon sources [79]. The isolates identified as deuteromycetes belonging to the genera Cladophialophora, Exophiala and Leptodontium and the ascomycete Pseudeurotium zonatum are toluene-degrading fungi, they use toluene as sole carbon and energy source [80].

The majority of filamentous fungi are unable to totally mineralize aromatic hydrocarbons; they only transform them into indirect products of decreased toxicity and increased susceptibility to decomposition with the use of bacteria suggesting that the interaction among fungi and bacteria is profitable for the process of petroleum hydrocarbon mineralization. Among the filamentous fungi participating in aliphatic hydrocarbon biodegradation are Cladosporium and Aspergillus, whereas fungi belonging to Cunninghamella, Penicillinum, Fusarium and Aspergillus can take part in aromatic hydrocarbon decomposition [81]. Fungal genera, namely, Amorphoteca, Neosartorya and Talaromyces were isolated from petroleum contaminated soil and proved to be the potential organisms for hydrocarbon degradation [82]. A group of fungi, namely, Aspergillus, Cephalosporium and Pencillium was also found to be potential degrader of crude oil hydrocarbons [83]. Fungal potentiality in PCBs degradation has been rarely explored. Several studies revealed that filamentous fungi can degrade PCBs. Among the filamentous fungi, the ligninolytic ones have been specifically investigated because of their extracellular, aspecific oxido-reductive enzymes that have been already successfully exploited in the degradation of many aromatic pollutants [84]. There have also been studies of PCB metabolism by ectomycorrhizal fungi [85] and other fungi such as Aspergillus niger [86]. Fungi are also reported to degrade standing timber, finished wood products, fibers, and a wide range of non 
cellulosic products such as plastics, fuels, paints, glues, drugs, and other human artifacts. Fungi are known to tolerate and detoxify metals by several mechanisms including valence transformation, extra and intracellular precipitation and active uptake [87]. Many species can adsorb cadmium, copper, lead, mercury, and zinc into their mycelium and spores. Sometimes the walls of dead fungi bind better than living ones. Systems using Rhiloprzs arrhizus have been developed for treating uranium and thorium [88]. Aspergillus niger AB10 during cadmium and $R$. arrhizus M1 during lead biosorption indicated that the cell surface functional groups of the fungus might act as ligands for metal sequestration resulting in removal of the metals from the aqueous culture media [89]. Furthermore, the proteins in the cell walls of AMF appear to have similar ability to sorb potentially toxic elements by sequestering them. There is evidence that AMF can withstand potentially toxic elements and glomalin produced on hyphae of AMF can sequester them [90]. AMF plays a significant ecological role in the phytostabilization of potentially toxic trace element polluted soils by sequestration and, in turn, help mycorrhizal plants survive in polluted soils.

The most widely researched fungi in regard to dye degradation are the ligninolytic fungi [91]. Nine strains of filamentous fungi were isolated by Abruscia et al. [79] from cinematographic film consisted of three species of Aspergillus i.e. A. ustus, A. nidulans var. nidulans, A. versicolor, as well as, Penicillium chrysogenum, Cladosporium cladosporioides, Alternaria alternata, Mucor racemosus, Phoma glomerata and Trichoderma longibrachiatum were able to biodegrade the gelatin emulsion with different rates of metabolic $\mathrm{CO}_{2}$ production. Filamentous fungi may degrade pesticides using two types of enzymatic systems: intracellular (cytochromes P450) and exocellular (lignin-degrading system mainly consisting in peroxidases and lactases). Each of these systems could also be induced or inhibited by pesticides, thus able to modulate their metabolism [92].

\subsection{Degradative capacities of algae and protozoa}

In spite of algae and protozoa are the important members of the microbial community in both aquatic and terrestrial ecosystems, reports are scanty regarding their involvement in hydrocarbon biodegradation [5]. Walker et al. [93] isolated an alga, Prototheca zopfi which was capable of utilizing crude oil and a mixed hydrocarbon substrate and exhibited extensive degradation of n-alkanes and isoalkanes as well as aromatic hydrocarbons. Cerniglia and Gibson [94] observed that nine cyanobacteria, five green algae, one red alga, one brown alga, and two diatoms could oxidize naphthalene. Protozoa, by contrast, had not been shown to utilize hydrocarbons, however, protozoa population have been shown to significantly reduce the number of bacteria available for hydrocarbon removal so their presence in a biodegradation system may not always be beneficial [95]. Rogerson and Berger [96] found no direct utilization of crude oil by protozoa cultured on hydrocarbon-utilizing yeasts and bacteria. Overall, the limited available evidence does not appear to suggest an ecologically significant role for algae and protozoa in the degradation of hydrocarbons in the environment [97]. Some research has demonstrated that certain fresh algae (e.g. Chlorella vulgaris, Scenedesmus platydiscus, S. quadricauda and S. capricornutum) are capable of uptaking and degrading PAHs [98]. 
Information on the interactions between pesticides andalgae were compiled by Kobayashi and Rittman [99], showing that not only algae were capable of bioaccumulating pesticides, but they were also capable of biotransforming some of these environmental pollutants.

Degradation of azo dyes by C. vulgaris and C. pyrenoidosa was made using dyes as carbon and nitrogen sources, but this was dependent on the chemical structure of the dyes [100]. The degradation was found to be an inducible catabolic process. C. vulgaris, Lyngbyala gerlerimi, Nostoc lincki, Oscillatoria rubescens, Elkatothrix viridis and Volvox aureus were able to decolorize and remove methyl red, orange II, G-Red (FN-3G), basic cationic, and basic fuchsin [101].

Species of Chlorella, Anabaena inacqualis, Westiellopsis prolifica, Stigeoclonium lenue, Synechoccus sp. tolerate heavy metals and several species of Chlorella, Anabaena and marine algae have been used for the removal of heavy metals, but the operational conditions limit the practical application of these organisms [102]. Metals are taken up by algae through adsorption. Metal chelation by unicellular algae has been reported. Biosorption of heavy metals by brown algae is also known since a long time, this includes sorption of heavy metals by a number of cell wall constituents such as alginate and fucoidan. Most of the research in this area has been carried out on marine and soil algae [103]. The microalga S. incrassatulus was reported to remove $\mathrm{Cr}(\mathrm{VI}), \mathrm{Cd}(\mathrm{II})$ and $\mathrm{Cu}(\mathrm{II})$ in continuous cultures [104]. Green algae were also reported in heavy metals bioremediation, C. sorokiniana for Cr(III) removal [105].

The protozoa are the main grazer on the degrading bacteria for organic contaminants, so the interaction between protozoa and degrading bacteria will affect the result of bacteria degradation directly. Mattison and Harayama [106] constructed a model for the food chain in order to study the influence of grazing bacteria of protozoa flagellate Heteromita globosa on the biodegradation of benzene and methylbenzene. They found that during the logarithmic growing period of flagellate population, the degrading rate of benzene and methylbenzene has improved 8.5 times by bacteria than before. The protozoa infusorians can obviously accelerate the biodegradation of heterogenous substances in the environment such as PAH. For example, the degradation rate of naphthalene can be improved by 4 times than before. There are several possible hypotheses about the mechanism of protozoa accelerating biodegradation of organic contaminants, which mainly include the following six parts: 1) the nutrient mineralization which improves the turnover of nutrients; 2) bacteria activation which controls the quantity, grazes the aged cells or excretes active substance; 3) selective grazing which reduces the competition to the resource and space and thus is good for the growth of degrading bacteria; 4 ) physical disturbance which can increase oxygen content and the surface of degraded matters; 5) direct degradation which can excrete special enzymes participating in the degradation; 6) sym-metabolism which offers energy and carbon resource for the bacteria during the degradation [107].

\section{Bioremediation and biodegradation}

The application of bioremediation as a biotechnological process involving microorganisms has become a crescent study field in microbiology, because of its increasing potential of solving 
the dangers of many pollutants through biodegradation. Microorganisms might be considered excellent pollutant removal tools in soil, water, and sediments, mostly due to their advantage over other bioremediation procedures [108]. Moreover, bioremediation using biodegradation represents a high impact strategy, but still a low cost way tool of removing pollutants, hence a very viable process to be applied. The principles of bioremediation are based on natural attenuation, bioaugmentation and biostimulation [109]. The simplest method of bioremediation is natural attenuation, in which soils are only monitored for variations in pollution concentrations to ensure that the pollutant transformation is active [110]. Bioaugmentation is usually applied in cases where natural active microbial communities are present in low quantities or even absent, wherein the addition of contaminant degrading organisms can accelerate the transformation rates [111]. In such cases, the adaptation of exogenous strains that exert highly efficient activities for pollutant transformation to new environments is a key challenge in implementation [112]. The capacity of a microbial population to degrade pollutants can be enhanced also by stimulation of the indigenous microorganisms by addition of nutrients or electron acceptors [109].

\subsection{Natural attenuation}

Natural attenuation or bioattenuation is the reduction of contaminant concentrations in the environment through biological processes (aerobic and anaerobic biodegradation, plant and animal uptake), physical phenomena (advection, dispersion, dilution, diffusion, volatilization, sorption/desorption), and chemical reactions (ion exchange, complexation, abiotic transformation). Terms such as intrinsic remediation or biotransformation are included within the more general natural attenuation definition [113]. Although, one of the most important components of natural attenuation is biodegradation, the change in form of compounds carried out by living creatures such as microorganisms. Under the right conditions, microorganisms can cause or assist chemical reactions that change the form of the contaminants so that little or no health risk remains. Natural attenuation occurs at most polluted sites. However, the right conditions must exist underground to clean sites properly. If not, cleanup will not be quick enough or complete enough. Scientists monitor these conditions to make sure natural attenuation is working. This is called monitored natural attenuation or (MNA). So, Monitored natural attenuation is a technique used to monitor or test the progress of natural attenuation processes that can degrade contaminants in soil and groundwater. It may be used with other remediation processes as a finishing option or as the only remediation process if the rate of contaminant degradation is fast enough to protect human health and the environment. Natural processes can then mitigate the remaining amount of pollution; regular monitoring of the soil and groundwater can verify those reductions [114].

When the environment is polluted with chemicals, nature can work in four ways to clean it up [115]: 1) Tiny bugs or microbes that live in soil and groundwater use some chemicals for food. When they completely digest the chemicals, they can change them into water and harmless gases. 2) Chemicals can stick or sorb to soil, which holds them in place. This does not clean up the chemicals, but it can keep them from polluting groundwater and leaving the site. 3) As pollution moves through soil and groundwater, it can mix with clean water. This reduces or 
dilutes the pollution. 4) Some chemicals, like oil and solvents, can evaporate, which means they change from liquids to gases within the soil. If these gases escape to the air at the ground surface, sunlight may destroy them.

If the natural attenuation is not quick enough or complete enough, bioremediation will be enhanced either by biostimulation or bioaugmentation.

\subsection{Biostimulation}

Biostimulation involving the addition of soil nutrients, trace minerals, electron acceptors, or electron donors enhances the biotransformation of a wide range of soil contaminants [115]. There are many examples of biostimulation of pollutants biodegradation by indigenous microorganisms. Trichloroethene and perchloroethene are reported to be completely converted to ethane by microorganisms in a short span of time with the addition of lactate during biostimulation [116]. Electron shuttles, such as humic substances (HS), may play a significant stimulation role in the anaerobic biotransformation of organic pollutants through enhancing the electron transfer speed. Anthraquinone-2,6-disulfonate (AQDS) from the category of HS can serve as an electron shuttle to promote the reduction of iron oxides and transformation of chlorinated organic contaminants [117]. Chen et al. [118] reported that the biostimulation of indigenous microbial communities by the addition of lactate and AQDS led to the enhanced rates of Pentachlorophenol PCP dechlorination by the dechlorinating and ironreducing bacteria in soils. Among various nutrient media, glycerol appeared to show the most favorable metabolic characteristics against phenol toxicity on the indigenous Rhizobium Ralstonia taiwanensis, leading to better degradation efficiency of the toxic pollutant [119]. Liliane et al. [120] observed that biostimulation was more efficient when compared to natural attenuation of biodiesel in contaminated soils. However, the comparative study of Bento et al. [121] revealed that bioaugmentation showed the greatest degradation potential and natural attenuation was more effective than biostimulation of soils contaminated with diesel oil. Results obtained by Yu et al. [122] indicate that autochthonous microbes may interact and even compete with the enriched consortium during polycyclic aromatic hydrocarbons biodegradation and the natural attenuation appeared to be the most appropriate way to remedy fluorene and phenanthrene contaminated mangrove sediments while biostimulation was more capable to degrade pyrene contaminated sediments.

\subsection{Bioaugmentation}

We can define bioaugmentation as the technique for improvement of the capacity of a contaminated matrix (soil or other biotope) to remove pollution by the introduction of specific competent strains or consortia of microorganisms [123]. The basic premise for this intervention is that the metabolic capacities of the indigenous microbial community already present in the biotope slated for cleanup will be increased by an exogenously enhanced genetic diversity, thus leading to a wider repertoire of productive biodegradation reactions [111]. Moreover, genetically engineered microorganisms (GEMs) exhibiting enhanced degradative capabilities encompassing a wide range of aromatic hydrocarbons have also potential for soil bioaugmen- 
tation [124]. It is thought that bioaugmentation approach should be applied when the biostimulation and bioattenuation have failed [111].

Many studies have shown that both abiotic and biotic factors influence the effectiveness of bioaugmentation, the most important abiotic factors are temperature, moisture, $\mathrm{pH}$ and organic matter content, however, aeration, nutrient content and soil type also determine the efficiency of bioaugmentation. Biotic factors, including competition between indigenous and exogenous microorganisms for limited carbon sources as well as antagonistic interactions and predation by protozoa and bacteriophages, also play essential roles in the final results of bioaugmentation [124].

The combination of bioaugmentation and biostimulation might be a promising strategy to speed up bioremediation. Both indigenous and exogenous microorganisms could benefit from biostimulation by the addition of energy sources or electron acceptors [111]. Bioaugmentationassisted phytoextraction using PGPR or AMF is also a promising method for the cleaning-up of soils contaminated by metals [123].

\section{Factors affecting microbial degradation}

Microorganisms can degrade numerous of organic pollutants owing to their metabolic machinery and to their capacity to adapt to inhospitable environments. Thus, microorganisms are major players in site remediation. However, their efficiency depends on many factors, including the chemical nature and the concentration of pollutants, their availability to microorganisms, and the physicochemical characteristics of the environment [111]. So, factors that influence the rate of pollutants degradation by microorganisms are either related to the microorganisms and their nutritional requirements (biological factors) or associated to the environment (environmental factors).

\subsection{Biological factors}

A biotic factor is the metabolic ability of microorganisms. The biotic factors that affect the microbial degradation of organic compounds include direct inhibition of enzymatic activities and the proliferation processes of degrading microorganisms [125]. This inhibition can occur for example if there is a competition between microorganisms for limited carbon sources, antagonistic interactions between microorganisms or the predation of microorganisms by protozoa and bacteriophages [126]. The rate of contaminant degradation is often dependent on the concentration of the contaminant and the amount of "catalyst" present. In this context, the amount of "catalyst" represents the number of organisms able to metabolize the contaminant as well as the amount of enzymes(s) produced by each cell. Furthermore, the extent to which contaminants are metabolized is largely a function of the specific enzymes involved and their "affinity" for the contaminant and the availability of the contaminant. In addition, sufficient amounts of nutrients and oxygen must be available in a usable form and in proper proportions for unrestricted microbial growth to occur [126]. Other factors that influence the rate of biodegradation by controlling the rates of enzyme catalyzed reactions are temperature, 
$\mathrm{pH}$ and moisture. Biological enzymes involved in the degradation pathway have an optimum temperature and will not have the same metabolic turnover for every temperature [127]. Indeed, the rate of biodegradation is decreased by roughly one-half for each $10^{\circ} \mathrm{C}$ decrease in temperature [159]. Biodegradation can occur under a wide-range of $\mathrm{pH}$; however, a $\mathrm{pH}$ of 6.5 to 8.5 is generally optimal for biodegradation in most aquatic and terrestrial systems. Moisture influences the rate of contaminant metabolism because it influences the kind and amount of soluble materials that are available as well as the osmotic pressure and $\mathrm{pH}$ of terrestrial and aquatic systems [128].

\subsection{Environmental factors}

Soil type and soil organic matter content affect the potential for adsorption of an organic compound to the surface of a solid. Absorption is an analogous process wherein a contaminant penetrates into the bulk mass of the soil matrix. Both adsorption and absorption reduce the availability of the contaminant to most microorganisms and the rate at which the chemical is metabolized is proportionately reduced [126]. Variations in porosity of the unsaturated and saturated zones of the aquifer matrix may influence the movement of fluids and contaminant migration in groundwater. The ability of the matrix to transmit gases, such as oxygen, methane and carbon dioxide, is reduced in fine grained sediments and also when soils become more saturated with water. This can affect the rate and type of biodegradation taking place [126].The oxidation-reduction potential of a soil provides a measurement of the electron density of the system. Biological energy is obtained from the oxidation of compounds in which electrons are transferred to various more oxidized compounds referred to as electron acceptors. A low electron density (Eh greater than $50 \mathrm{mV}$ ) indicates oxidizing, aerobic conditions, whereas high electron density (Eh less than $50 \mathrm{mV}$ ) indicates reducing, anaerobic conditions [126].

\section{Degradation by genetically engineered microorganisms}

As mentioned above, bioaugmentation and biostimulation are methods that can be applied to accelerate the recovery of polluted sites. In the late 1970s and early 1980s, bacterial genes encoding catabolic enzymes for recalcitrant compounds started to be cloned and characterized. Soon, many microbiologists and molecular biologists realized the potential of genetic engineering for addressing biodegradation [128]. A genetically engineered microorganism (GEM) or modified microorganism (GMM) is a microorganism whose genetic material has been altered using genetic engineering techniques inspired by natural genetic exchange between microorganisms. These techniques are generally known as recombinant DNA technology. Genetically engineered microorganisms (GEMs) have shown potential for bioremediation of soil, groundwater and activated sludge, exhibiting the enhanced degrading capabilities of a wide range of chemical contaminants [129]. As soon as the prospect of releasing genetically modified microorganisms for bioremediation became a reality, much of the research effort in the field was aimed at biosafety and risk assessment [128]. 
There are at least four principal approaches to GEM development for bioremediation application [11]. These include: 1) Modification of enzyme specificity and affinity; 2) Pathway construction and regulation;3) Bioprocess development, monitoring and control; 4) Bioaffinity bioreporter sensor applications for chemical sensing, toxicity reduction and end point analysis.

\subsection{Genetically engineered microorganisms}

Molecular biology offers the tools to optimize the biodegradative capacities of microorganisms, accelerate the evolution of "new" activities, and construct totally "new" pathways through the assemblage of catabolic segments from different microbes [130].

Genes responsible for degradation of environmental pollutants, for example, toluene, chlorobenzene acids, and other halogenated pesticides and toxic wastes have been identified. For every compound, one separate plasmid is required. It is not like that one plasmid can degrade all the toxic compounds of different groups. The plasmids are grouped into four categories: 1) OCT plasmid which degrades, octane, hexane and decane; 2) XYL plasmid which degrades xylene and toluenes, 3) CAM plasmid that decompose camphor and 4) NAH plasmid which degrades naphthalene [130].

The potential for creating, through genetic manipulation, microbial strains able to degrade a variety of different types of hydrocarbons has been demonstrated by Friello et al. [131]. They successfully produced a multiplasmid-containing Pseudomonas strain capable of oxidizing aliphatic, aromatic, terpenic and polyaromatic hydrocarbons.

Pseudomonas putida that contained the XYL and NAH plasmid as well as a hybrid plasmid derived by recombinating parts of CAM and OCT developed by conjugation could degrade camphor, octane, salicylate, and naphthalene [129] and could grew rapidly on crude oil because it was capable of metabolizing hydrocarbons more efficiently than any other single plasmid [131].

This product of genetic engineering was called as superbug (oil eating bug). The plasmids of P. putida degrading various chemical compounds are TOL (for toluene and xylene), RA500 (for 3, 5-xylene) pAC 25 (for 3-cne chlorobenxoate), pKF439 (for salicylate toluene). Plasmid WWO of $P$. putida is one member of a set of plasmids now termed as TOL plasmid. It was the first living being to be the subject of an intellectual property case. At that point, it seemed that molecular techniques, either through plasmid breeding or sheer genetic engineering, could rapidly produce microbes with higher catalytic abilities, able to basically degrade any environmental pollutant [129].

Reports on the degradation of environmental pollutants by genetically engineered microorganisms are focused on genetically engineered bacteria using different genetic engineering technologies: Pathway modification, modification of substrate specificity by Comamonas testosteroni VP44 [132].

The application of genetic engineering for heavy metals removal has aroused great interest. For example, Alcaligenes eutrophus AE104 (pEBZ141) was used for chromium removal from industrial wastewater [133] and the recombinant photosynthetic bacterium, Rhodopseudomonas 
palustris, was constructed to simultaneously express mercury transport system and metallothionein for $\mathrm{Hg}^{2+}$ removal from heavy metal wastewater [134].

For polychlorinated biphenyls degradation, chromosomally located PCB catabolic genes of $R$. eutropha A5, Achromobacter sp. LBS1C1, and A. denitrificans JB1 were transferred into a heavy metal resistant strain $R$. eutropha $\mathrm{CH} 34$ through natural conjugation [11].

Genetic engineering of endophytic and rhizospheric bacteria for use in plant associated degradation of toxic compounds in soil is considered one of the most promising new technologies for remediation of contaminated environmental sites [53]. To select a suitable strain for gene recombination and inoculation into the rhizosphere, there are three criteria that has been recommended: first, the strain should be stable after cloning and the target gene should have a high expression, second, the strain should be tolerant or insensitive to the contaminant; and third, some strains can survive only in several specific plant rhizosphere [135]. Many bacteria in the rhizosphere show only limited ability in degrading organic pollutants. With the development of molecular biology, the genetically engineered rhizobacteria with the contaminant-degrading gene are constructed to conduct the rhizoremediation [58]. Examples about the molecular mechanisms involved in the degradation of some pollutants such as trichloroethylene (TCE) and PCBs has been studied [136].

For heavy metals, Sriprang et al. [136] introduced Arabidopsis thaliana gene for phytochelatin synthase (PCS; PCSAt) into Mesorhizobium huakuii subsp. rengei strain B3 and then established the symbiosis between M. huakuii subsp. rengei strain B3 and Astragalus sinicus. The gene was expressed to produce phytochelatins and accumulate $\mathrm{Cd}^{2+}$, under the control of bacteroidspecific promoter, the nifH gene [137].

Finally, the use of GEM strains as an inoculum during seeding would preclude the problems associated with competition between strains in a mixed culture. However, there is considerable controversy surrounding the release of such genetically engineered microorganisms into the environment, and field testing of these organisms must therefore be delayed until the issues of safety and the potential for ecological damage are resolved [138].

\subsection{Obstacles associated with the use of GEM in bioremediation applications}

While genetic engineering has produced numerous strains able to degrade otherwise intractable pollutants in a Petri dish or in a bioreactor, the practical translation of this research into actual in situ bioremediation practices has been quite scanty [129]. One major issue in this respect is the growing realization that the strains and bacterial species that most frequently appear in traditional enrichment procedures are not the ones performing the bulk of biodegradation in natural niches and may not even be any good as bioremediation mediators. The use of stable isotope probing (SIP) and equivalent methods in microbial ecology have revealed that Pseudomonas, Rhodococcus, and the typical aerobic fast growers that are widely favored as hosts of biodegradation related recombinant genes are far less significant under natural conditions [138]. Furthermore, using fast-growers as agents for biodegradation is the inevitable buildup of unwelcome biomass. As an alternative, the optimal clean-up agent would be the one that displays a maximum catalytic ability with a minimum of cell mass. The expression of 
biodegradation genes can be artificially uncoupled from growth with the use of stationaryphase promoters or starvation promoters [139]. In addition, the recent advances in the area of recombinant DNA technologies have paved the way for conceptualizing "suicidal genetically engineered microorganisms" (S-GEMS) to minimize such anticipated hazards and to achieve efficient and safer decontamination of polluted sites [140]. In some cases, whether the introduced bacterium is recombinant or not makes little difference, because the problem is that of implantation of foreign microbes in an unfamiliar territory. The introduction of bacterial biomass in an existing niche may create a palatable niche for protozoa that prevents the bacterial population to grow beyond a certain level [141]. Ingenious approaches have been developed to circumvent this problem, including encapsulation of the inoculum in a polymeric matrix or protection in plastic tubing [142].

The efficacy of a desired in-situ catalytic activity (biodegradation or otherwise) depends first on its presence in the target site. One key enzyme may not be there, or it may preexist in the site but not be manifested. Alternatively, it can be hosted by just a very minor part of the whole microbial population, so that its factual expression in the site might not be significant [129].

A field release of $P$. fluorescens HK44 for bioremediation application has been successfully conducted on moderately large-scale and controlled field condition [143]. However, the future application of genetically engineered bacteria for pollution remediation will not be free from the risks associated with their release in the environment. The future risk regarding use of other engineered bacteria is still unclear. Therefore, the future perspectives of engineered bacterial strains under the field conditions will be the focus of review, which may help us to assess the obstacles related with application of genetically engineered bacteria in environmental bioremediation.

The major problem encountered in successful bioremediation technology pertains to hostile field conditions for the engineered microbes. Besides, the molecular applications are mainly confined to only few well characterized bacteria such as E. coli, P. putida, B. subtilis, etc. Other bacterial strains need to be tried for developing the engineered microbes. The specific characteristic of open biotechnological applications has clearly necessitated the development of engineered bacterial strains to meet the new challenges. The main concern is to construct GE bacteria for field release in bioremediation with an adequate degree of environmental certainty. Efforts should be made to examine the performance of engineered bacteria in terms of their survival, potential of horizontal gene transfer, which may affect the indigenous microflora within a complex environmental situation. Often the novel scientific researches always give rise to still more fascinating questions pertaining to public concern. In the majority cases, the bacteria designed for bioremediation processes have been designed for specific purpose under the laboratory conditions, ignoring the field requirement and other complex situations. However, there is no evidence that the deliberate release of GE bacteria for bioremediation has caused a measurable adverse impact on the natural microbial community. At least the overstated idea of risk appraisal has fuelled so much debate and triggered so many research efforts, which have immensely contributed a lot in the field of environmental microbiology. However, survival of the GE bacteria in complex environmental situations is still a big question, needs to be addressed in the light of latest findings [144]. 


\section{Conclusion}

Microbial activities are very important for the renewal of our environment and maintenance of the global carbon cycle. These activities are included in the term biodegradation. Amid the substances that can be degraded or transformed by microorganisms are a huge number of synthetic compounds and other chemicals having ecotoxicological effects like hydrocarbons and heavy metals. However, in most cases this statement concerns potential degradabilities which were estimated in the laboratory by using selected cultures and under ideal growth conditions. Due to a whole range of factors: competition with microorganisms, insufficient supply with essential substrates, unfavorable external conditions (aeration, moisture, $\mathrm{pH}$, temperature), and low bioavailability of the pollutant, biodegradation in natural conditions is lesser. So, environmental biotechnology has the objective of tackling and solving these problems so as to permit the use of microorganisms in bioremediation technologies. For this reason, it is necessary to support the activities of the indigenous microorganisms in polluted biotopes and to enhance their degradative abilities by bioaugmentation or biostimulation. Genetic engineering is also used to improve the biodegradation capabilities of microorganisms. Nevertheless, there are many risks associated to the use of GEM in the field. Whether or not such approaches are ultimately successful in bioremediation of pollutants may make a difference in our ability to reduce wastes, eliminate industrial pollution, and enjoy a more sustainable future.

\section{Acknowledgements}

The authors are grateful for the financial and scientific support rendered by Microbial Biotechnology Laboratory of Faculty of Sciences and Innovation City, SMBA University, Fez, Morocco.

\section{Author details}

Nezha Tahri Joutey, Wifak Bahafid, Hanane Sayel and Naïma El Ghachtouli*

*Address all correspondence to: naimaelghachtouli@yahoo.com

Microbial Biotechnology Laboratory, Sidi Mohammed Ben Abdellah University, Faculty of Science and Technics, Fez, Morocco

\section{References}

[1] Alexander M. Biodegradation and Bioremediation, San Diego CA 1994. Academic Press. 
[2] Marinescu M, Dumitru M and Lacatusu A. Biodegradation of Petroleum Hydrocarbons in an Artificial Polluted Soil. Research Journal of Agricultural Science 2009; 41(2).

[3] Bennet JW, Wunch KG and Faison B D. Use of fungi biodegradation. Manual of environmental microbiology 2002, 2nd ed., ASM Press: Washington, D.C., 960-971.

[4] Fritsche W and Hofrichter M. Aerobic Degradation by Microorganisms 2008 in Biotechnology Set, Second Edition (eds H.-J. Rehm and G. Reed), Wiley-VCH Verlag GmbH, Weinheim, Germany. doi: 10.1002/9783527620999.ch6m

[5] Das N and Chandran P. Microbial Degradation of Petroleum Hydrocarbon Contaminants: An Overview SAGE-Hindawi Access to Research Biotechnology. Research International. Volume 2011, Article ID 941810, 13 pages. Doi:10.4061/2011/941810.

[6] Pramila R., Padmavathy K, Ramesh KV and Mahalakshmi K. Brevibacillus parabrevis, Acinetobacter baumannii and Pseudomonas citronellolis - Potential candidates for biodegradation of low density polyethylene (LDPE). Journal of Bacteriology Research 2012; 4(1) 9-14.

[7] Mrozik A, Piotrowska-Seget Z and Labuzek S. Bacterial degradation and bioremediation of Polycyclic Aromatic Hydrocarbons. Polish Journal of Environmental Studies 2003; 12 (1) 15-25.

[8] Leitão AL. Potential of Penicillium Species in the Bioremediation Field. International Journal of Environmental Resarch. Public Health 2009; 6 1393-1417; doi:10.3390/ ijerph6041393.

[9] Diez MC. Biological Aspects involved in the degradation of organic pollutants. Journal of Soil Science and Plant Nutrition. [online] 2010; 10 (3) 244-267. ISSN 0718-9516.

[10] Seo JS, Keum YS and Li QX. Bacterial Degradation of Aromatic Compounds. International Journal of Environmental Resarch. Public Health 2009, 6, 278- 309; doi:10.3390/ ijerph6010278.

[11] Menn FM, Easter JP and Sayler GS. Genetically Engineered Microorganisms and Bioremediation, in Biotechnology: Environmental Processes II 2008; 11b, Second Edition (eds H.-J. Rehm and G. Reed), Wiley-VCH Verlag GmbH, Weinheim, Germany. doi: 10.1002/9783527620951.ch21.

[12] Lesley A. Ogilvie and Penny R. Hirsch. 2012. Microbial ecological theory: Current perspectives.

[13] McMurry J (2000). In Aromatic hydrocarbons. Organic Chmistry.5th ed brooks/cole: Thomas learning. New York, pp. 120-180.

[14] Okere UV and Semple KT. Biodegradation of PAHs in 'Pristine' Soils from Different Climatic Regions. Okere and Semple. J BioremedBiodegrad 2012, S:1. http:// dx.doi.org/10.4172/2155-6199.S1-006. 
[15] Seeger M, Hernández M, Méndez V, Ponce B, Córdova1 M and González M. Bacterial degradation and bioremediation of chlorinated herbicides and biphenyls. Journal of Soil Science and Plant Nutrition 2010; 10 (3) 320-332.

[16] Vargas JM. Pesticide degradation. Journal of Arboriculture 1975; 1(12) 232- 233.

[17] Raffi F, Hall JD and Cernigila, CE. Mutagenicity of azo dyes used in foods, drugs and cosmetics before and after reduction by Clostridium species from the human intestinal tract. Food and chemical Toxicology 1997; 35 897-901.

[18] Vandevivere PC, Bianchi R, Verstraete W. Treatment and reuse of wastewater from the textile wet-processing industry: review of emerging technologies. Journal of Chemical Technology and Biotechnology 1998; 72 289-302.

[19] Verma P, Madamwar, D. Decolorization of synthetic dyes by a newly isolated strain of Serratia marcescers. World Journal of Microbiology and Biotechnology 2003; 19 615618.

[20] Petrucci RH, Harwood WS and Herring FG, General Chemistry (8th ed., PrenticeHall 2002), p.1025-26.

[21] Lloyd JR and Lovley DR. Microbial detoxification of metals and radionuclides. Current Opinion in Biotechnology 2001; 12 248-253.

[22] Yakimov MM, Timmis KN and Golyshin PN. Obligate oil-degrading marine bacteria. Current Opinion in Biotechnology, 2007; 18(3) 257-266.

[23] Grishchenkov VG, Townsend RT, McDonald TJ, Autenrieth RL, Bonner JS, Boronin AM Degradation of petroleum hydrocarbons by facultative anaerobic bacteria under aerobic and anaerobic conditions. Process Biochemistry 2000; 35(9) 889-896.

[24] Wiedemeier TH, Miller RN and Wilson JT. Significance of anaerobic processes for the Intrinsic bioremediation of fuel hydrocarbons: In, Proceedings of the Petroleum Hydrocarbons and Organic Chemicals in Groundwater - Prevention, Detection, and Remediation Conference, November 29 - December 1, 1995, Houston Texas.

[25] Floodgate G. The fate of petroleum in marine ecosystems. In Petroleum Microbiology, R. M. Atlas, Ed., pp. 355-398, Macmillion, New York, NY, USA, 1984.

[26] Kafilzadeh F, Sahragard P, Jamali H and Tahery Y. Isolation and identification of hydrocarbons degrading bacteria in soil around Shiraz Refinery. African Journal of Microbiology Research 2011; 4(19) 3084-3089.

[27] Fritsche $\mathrm{W}$ and Hofrichter M. Aerobic degradation of recalcitrant organic compounds by microorganisms, in environmental biotechnology: Concepts and applications (eds H.-J. Jördening and J. Winter), Wiley-VCH Verlag GmbH \& Co. KGaA, Weinheim, FRG. 2005 doi: 10.1002/3527604 286.ch7. 
[28] Seeger M, Cámara B, Hofer B. Dehalogenation, denitration, dehydroxylation, and angular attack on substituted biphenyls and related compounds by a biphenyl dioxygenase. Journal of Bacteriology 2001; 183 3548-3555.

[29] Petric I, Hrak D, Fingler S, Vonina E, Cetkovic H, Begonja A Kolar and UdikoviKoli N. Enrichment and characterization of PCB-Degrading bacteria as potential seed cultures for bioremediation of contaminated soil. Food Technology and Biotechnology 2007; 45(1)11-20.

[30] Taguchi K, Motoyama M and Kudo T. PCB/biphenyl degradation gene cluster in Rhodococcus rhodochrousK37, is different from the well-known bph gene clusters in Rhodococcus sp. P6, RHA1, and TA42. RIKEN Review 2001; 42. Focused on Ecomolecular Science Research.

[31] Struthers JK, Jayachandran K, Moorman TB. Biodegradation of atrazine by Agrobacterium radiobacter $\mathrm{J} 14 \mathrm{a}$ and use of this strain in bioremediation of contaminated soil. Applied of Environonmental Microbiology 1998; 64 3368-3375.

[32] Surekha Rani M, Lakshmi V, Suvarnalatha Devi KP, Jaya Madhuri R, Aruna S, Jyothi K, Narasimha G and Venkateswarlu K. Isolation and characterization of a chlorpyrifos degrading bacterium from agricultural soil and its growth response. African Journal of Microbiology Research 2008; (2) 026-031.

[33] Kanade SN, Ade1 AB and Khilare VC. Malathion Degradation by Azospirillum lipoferum Beijerinck. Science Research Reporter 2012; 2(1) 94-103.

[34] Dos Santos AB, Cervantes JF, Van Lier BJ. Review paper on current technologies for decolourisation of textile wastewaters: perspectives for anaerobic biotechnology. Bioresource Technology 2007; 98 2369-2385.

[35] Lodato A, Alfieri F, Olivieri G, Di Donato, Marzocchella A, Salatino A, P. Azo-dye conversion by means of Pseudomonas sp. OX1. Enzyme and Microbial Technology 2007; 41 646-652.

[36] Chaube P, Indurkar H, Moghe S. Biodegradation and decolorisation of dye by mix consortia of bacteria and study of toxicity on Phaseolus mungo and Triticum aestivum. Asiatic Journal of Biotechnology Resources 2010; 01 45-56.

[37] Hong Y, Xu M, Guo J et al. Respiration and growth of Shewanella decolorations S12 with an azo compound as the sole electron acceptor. Applied and Environmental Microbiology 2007; 73 64-72.

[38] Khalid A, Arshad M, and Crowley D. Bioaugmentation of Azo Dyes. The Handbook of Environmental Chemistry 2010; 9.

[39] Garbisu C, Alkorta I. Phytoextraction: A cost-effective plant based technology for the removal of metals from the environment. Bioresource Technology 2001; 77(3) 229-236. 
[40] Fern'andez PM, Martorell MM, Fari na JI, and Figueroa LIC., Removal Efficiency of $\mathrm{Cr}^{6+}$ by Indigenous Pichia sp. Isolated from Textile Factory Effluent. The Scientific World Journal. 2012, Article ID 708213, 6 pages doi:10.1100/2012/708213.

[41] Sayel H, Bahafid W, Tahri-Joutey N, Derraz K, Fikri-Benbrahim K, Ibnsouda-Koraichi S and El Ghachtouli N. Cr(VI) reduction by Enterococcus gallinarum isolated from tannery waste-contaminated soil. Annal of Microbiology. DOI 10.1007/ s13213-011-0372-9.

[42] Zhu W., Chai L., Ma Z., Wang Y., Xiao H. and Zhao K. Anaerobic reduction of hexavalent chromium by bacterial cells of Achromobacter sp. StrainCh1. Microbiological Research 2008; 163 616-623.

[43] Yee N, Ma J, Dalia A, Boonfueng T, and Kobayashi DY. Se(VI) Reduction and the Precipitation of $\mathrm{Se}(0)$ by the Facultative Bacterium Enterobacter cloacae SLD1a-1 Are Regulated by FNR. Applied and environmental microbiology 2007; 73(6) 1914-1920.

[44] Gao W and Francis AJ. Reduction of Uranium(VI) to Uranium(IV) by Clostridia. Applied and environmental microbiology 2008; 74(14) 4580-4584.

[45] Brim H, McFarlan SC, Fredrickson JK, Minton KW, Zhai M, Wackett LP, Daly MJ. Engineering Deinococcusradiodurans for metal remediation in radioactive mixed waste environments. Nature Biotechnology 2000; 18(1) 85-90. doi:10.1038/71986. PMID 10625398.

[46] De Jaysankar, Ramaiah N and Vardanyan L. Detoxification of toxic heavy metals by marine bacteria highly resistant to mercury. Marine Biotechnology 2008; 10(4) 471-477.

[47] Takeuchi F and Sugio T. Volatilization and Recovery of Mercury from Mercury-Polluted Soils and Wastewaters Using Mercury-Resistant Acidithiobacillus ferrooxidans strains SUG 2-2 and MON-1.Environmental Sciences 2006; 13(6) 305-316.

[48] White C, Sharman AK, Gadd GM: An integrated microbial process for the bioremediation of soil contaminated with toxic metals. Nature Biotechnology1998; 16 572-575.

[49] PinakiSar, Sufia K. Kazy, S.F. D'Souza. Radionuclide remediation using a bacterial biosorbent. International Biodeterioration\& Biodegradation 2004; 54(2-3) 193-202.

[50] Adarsh VK, Madhusmita Mishra, SanhitaChowdhury, 2M. Sudarshan, A.R. Thakur and 1S. Ray Chaudhuri. Studies on Metal Microbe Interaction of Three Bacterial Isolates From East Calcutta Wetland OnLine Journal of Biological Sciences 2007; 7(2) 80-88.

[51] Tahri-Joutey N, Bahafid W, Sayel H, El Abed S and El Ghachtouli N. Remediation of hexavalent chromium by consortia of indigenous bacteria from tannery waste-contaminated biotopes in Fez, Morocco. International Journal of Environmental Studies $2011 ;(686)$ 901-912. 
[52] Jadhav JP, Kalyani DC, Telke AA, Phugare SS, Govindwar SP. Evaluation of the efficacy of a bacterial consortium for the removal of color, reduction of heavy metals, and toxicity from textile dye effluent. Bioresource Technology 2010; 101(1) 165-173.

[53] Divya B and Deepak Kumar M. Plant-Microbe Interaction with Enhanced Bioremediation. Research Journal of BioTechnology. 2011; 6 (4).

[54] Saharan BS, Nehra V. Plant Growth Promoting Rhizobacteria: A Critical Review Life Sciences and Medicine Research, Volume 2011: LSMR-21.

[55] Hontzeas N, Zoidakis J and Glick BR. Expression and characterization of 1-aminocyclopropane-1-carboxylate deaminase from the rhizobacterium Pseudomonas putida UW4: A key enzyme in bacterial plant growth promotion. Biochimica et Biophysica Acta 2004; 1703 11-19.

[56] Ma B, Chen HH, He YandXu JM. Isolations and consortia of PAH-degrading bacteria from the rhizosphere of four crops in PAH-contaminated field. 2010 19th World Congress of Soil Science, Soil Solutions for a Changing World.

[57] Leigh BM, Prouzova P, Mackova M, Macek T, Nagle DP and Fletcher Kinuthia Mwangi JS. Polychlorinated Biphenyl (PCB)-Degrading Bacteria Associated with Trees in a PCB-Contaminated Site. Applied and Environmental Microbiology 2006; 4(72) 2331-2342.

[58] Glick BR. Using soil bacteria to facilitate phytoremediation. Biotechnology Advances. 2010; 28 367-374.

[59] Jing Y, He Z, Yang X. Role of soil rhizobacteria in phytoremediation of heavy metal contaminated soils. Journal of Zhejiang University Sciences 2007; 8 192-207.

[60] Rossman AY. Microfungi: Molds, mildews, rusts and smuts in our living resources. Washington, DC: U.S. Department of the Interior National Biological Service 1995.

[61] Spellman F. R. Ecology for non ecologists. 2008. Page 176.

[62] Matavuly MN and Molitoris HP. Marine fungi degraders of poly-3-hydroxyalkanoate based plastic materials. Proceedings for Natural Sciencespublished by MaticaSrpska 2009; 116 253-265.

[63] Khan AG. Mycorrhizoremediation an enhanced form of phytoremediation. Journal of Zhejiang University Science 2006 7(7) 503-514.

[64] Mörtberg M, Neujahr HY, Uptake of phenol in Trichosporon cutaneum, Journal of Bacteriology1985; 161 615-619.

[65] Bartha R. Biotechnology of petroleum pollutant degradation, Microbial Ecology1986. 12 155-172.

[66] De Cássia Miranda R, de Souza CS, de Barros Gomes E, Lovaglio RB, Lopes CE and de Fátima Vieira de Queiroz Sousa M. Biodegradation of Diesel Oil by Yeasts Isolat- 
ed from the Vicinity of Suape Port in the State of Pernambuco -Brazil. Brazilian archives of biology and technology 2007; 50(1)147-152.

[67] Mucha K, Kwapisz E, Kucharska U and Okruszeki A. Mechanism of aniline degradation by yeast strain Candida methanosorbosa BP-6. Polish journal of microbiology 2010; 59(4) 311-315.

[68] Ijah UJJ. Studies on relative capabilities of bacterial and yeast isolates from tropical soil in degradating crude oil. Waste Manage. 1998; 18293.

[69] Fritsche W, Hofrichter M, Aerobic degradation by microorganisms, in: Biotechnology. Vol. 11b, Environmental Processes, (-Rehm, H.-J., Reed, G., Eds.), Wiley-VCH, Weinheim 2000, pp. 145-167.

[70] Sasek V, Volfova O, Erbanova P, Vyas B R M, Matucha M. Degradation of PCBs by white rot fungi, methylotrophic and hydrocarbon utilizing yeasts and bacteria. Biotechnology Letters 1993; 15 521-526.

[71] Eaton D C. Mineralization of polychlorinated biphenyls by Phanerochaete chrysosporium: a ligninolytic fungus. Enzymeand Microbial Technology 1985; 7 194-196.

[72] P. Cabras, M. Meloni, F. M. Pirisi, G. A. Farris and F. Fatichenti. Yeast and pesticide interaction during aerobic fermentation. Applied Microbiology and Biotechnology 1988; 29(2-3) 298-301, DOI:10.1007/BF01982920.

[73] Wang J, Chen C. Biosorption of heavy metals by Saccharomyces cerevisiae: A Review. Biotechnology Advances 2006; 24: 427-451.

[74] Bahafid W, Sayel H, Tahri-Joutey N and EL Ghachtouli N. Removal Mechanism of Hexavalent Chromium by a Novel Strain of Pichia anomala Isolated from Industrial Effluents of Fez (Morocco). Journal of Environmental Science and Engineering 2011; 5 980-991.

[75] Bahafid W, Tahri-Joutey N, Sayel H, Iraqui-Houssaini M and El Ghachtouli N. 2012.Chromium adsorption by three yeast strains isolated from sediments in Morocco. DOI: 10.1080/01490451.2012.705228.

[76] KsheminskaH P., Taras M. Honchar, Galyna Z. Gayda, Mykhailo V. Gonchar. Extracellular chromate-reducing activity of the yeast cultures. Central European Science Journals 2006; 1(1) 137-149.

[77] Ksheminska H, Fedorovych D, Honchar T, Ivash M and Gonchar M. Yeast Tolerance to Chromium Depends on Extracellular Chromate Reduction and $\mathrm{Cr}$ (III) Chelation. Food Technology and Biotechnology 2008; 46 (4) 419-426.

[78] SaiSubhashini S, Kaliappan S, Velan M. Removal of heavy metal from aqueous solution using Schizosaccharomyces pombe in free and alginate immobilized cells. 2nd International Conference on Environmental Science and Technology 2011; 6107-111. 
[79] Abruscia C., Marquinaa D., Del Amob A., Catalina F. Biodegradation of cinematographic gelatin emulsion by bacteria and filamentous fungi using indirect impedance technique. International Biodeterioration and Biodegradation 2007; 60 137-14.

[80] Francesc X. Prenafeta-Boldu, Andrea Kuhn, Dion M. A. M. Luykx, HeidrunAnke, Johan W. van Groenestijn and Jan A. M. de Bont. Isolation and characterisation of fungi growing on volatile aromatic hydrocarbons as their sole carbon and energy source. Mycological Research 2001; 105(4) 477-484.

[81] Steliga T. Role of fungi in biodegradation of Petroleum Hydrocarbons in Drill Waste. Polish Journal of Environmental Studies 2012; 21(2) 471-479.

[82] Chaillan F, Le Flèche A, Bury E et al. Identification and biodegradation potential of tropical aerobic hydrocarbon degrading microorganisms. Research in Microbiology 2004; 155(7) 587-595.

[83] Singh H, Mycoremediation: Fungal bioremediation, Wiley-Interscience, New York, NY, USA, 2006.

[84] Tigini V, Di Toro S, Belardo A, Prigione V, Fava F and Varese GC. Identification and characterization of the active mycoflora of a consortium in the bioremediation of a soil historically contaminated by polychlorinated biphenyls (PCBs). $4^{\text {th }}$ European bioremediation conference.

[85] Donnelly PK, Fletcher JS. PCB metabolism by ectomycorrhizal fungi. Bulletin of Environmental Contamination and Toxicology1995; 54 507-513.

[86] Dmochewitz S, Ballschmiter K. Microbial transformation of technical mixtures of polychlorinated biphenyls (PCB) by the fungus Aspergillus niger. Chemosphere 1988; 17 111-121.

[87] Gadd GM. Interaction of fungi with toxic metals. New Phytologist 1993; 124 25-60.

[88] Treen-Sears ME, Martin SM and Volesky B. Propagation of Rhiloprzs juvanicus biosorbent. Applied and Environmental Microbiology 198; 448 137-141.

[89] Pal TK, Bhattacharyya S, Basumajumdar A. Cellular distribution of bioaccumulated toxic heavy metals in Aspergillus niger and Rhizopus arrhizus. International Journal of pharma and bio sciences 2010; 1(2) 1-6.

[90] Gonzalez-Chavez MC, Carrillo-Gonzalez R, Wright SF, Nichols K. The role of glomalin, a protein produced by arbuscularmycorrhizal fungi, in sequestering potentially toxic elements. Environmental Pollution 2004; 130(3) 317-323. [doi:10.1016/j.envpol. 2004.01.004].

[91] Bumpus JA. Biodegradation of azo dyes by fungi. In: Arora, D.K. (Ed.), Fungal Biotechnology in Agricultural, Food and Environmental Applications. Marcel Dekker, New York, pp. 2004 457-480.

[92] Chaplain V, Mamy L, Vieuble'-Gonod L, Mougin C, Benoit P, Barriuso E and Nélieu S. Fate of Pesticides in Soils: Toward an Integrated Approach of Influential Factors, 
Pesticides in the Modern World - Risks and Benefits, Margarita Stoytcheva (Ed.) 2011 ISBN: 978-953-307-458-0.

[93] Walker JD, Colwell RR, Vaituzis Z and Meyer SA. Petroleum-degrading achlorophyllous alga Protothecazopfi. Nature (London) 1975; 254 423-424.

[94] Cerniglia CE and Gibson DT. Metabolism of naphthalene by Cunninghamella elegans. Applied and Environmental Microbiology 1977; 34 363-370.

[95] Stapleton RD and Jr.,V.P. Singh. Biotransformations: Bioremediation Technology for Health and Environmental protection. 2002.

[96] Rogerson A, and Berger J. Effect of crude oil and petroleum-degrading microorganisms on the growth of freshwater and soil protozoa. Journal of General Microbiology $1981 ; 124$ 53-59.

[97] Bossert I, and Bartha R. 1984. The fate of petroleum in soil ecosystems, p. 434-476. In R. M. Atlas (ed.), Petroleum microbiology. Macmillan Publishing Co., New York.

[98] X.-C. Wang and H.-M. Zhao. 2007. Uptake and Biodegradation of Polycyclic Aromatic Hydrocarbons by Marine Seaweed. Journal of Coastal Research, SI 50 (Proceedings of the 9th International Coastal Symposium), 1056 - 1061. Gold Coast, Australia, ISSN 0749.0208.

[99] Kobayashi H and Rittman BE. Microbial removal of hazardous organic compounds. Environmental Science and Technology 1982; 16 170A-183A.

[100] Jinqi I and Houtian O. Degradation of azo dyes by algae. Environmental Pollution 1992; 75, 273-278.

[101] El-Sheekh MM, Gharieb MM and Abou-El-Souod GW. Biodegradation of dyes by some green algae and cyanobacteria. International biodeterioration and biodegrdation 2009; 63 699-704.

[102] Dwivedi S. Bioremediation of heavy metal by algae: Current and future perspective. Journal of Advanced Laboratory Research in Biology 2012; 3(3).

[103] Davis TA, Volesky B, Mucci A. A review of the biochemistry of heavy metal biosorption brown algae. Water Research 2003;37:4311-30.

[104] Peňa-Castro JM, Martínez-Jerónimo F, Esparza-García F, Caňizares-Villanueva RO. Heavy metals removal by the microalga Scenedesmus incrassatulus in continuous cultures. Bioresource Technology 2004; 94 219-222.

[105] Akhtar N, Iqbal M, Iqbal ZS and Iqbal J. Biosorption characteristics of unicellular green alga Chlorella sorokiniana immobilized in loofa sponge for removal of $\mathrm{Cr}(\mathrm{III})$. Journal of Environmental Sciences 2008; 20 231-239. 
[106] Mattison RG, Taki H, Harayama S. The soil flagellate Heteromita globosa accelerates bacterial degradation of alkylbenzenesthrough grazing and acetate excretion in batch culture.Microbial Ecology 2005; 49: 142-150.

[107] Chen X., Liu M., Hu F., Mao X. and Li H. Contributions of soil micro-fauna (protozoa and nematodes) to rhizosphere ecological functions. ActaEcologicaSinica 2007; 27(8) 3132-3143.

[108] Demnerova K, Mackova M, Spevakova, V, Beranova K, Kochankova L, Lovecka P, Ryslava, E, Macek T. Two approaches to biological decontamination of groundwater and soil polluted by aromatics characterization of microbial populations. International Microbiology 2005; 8 205-211.

[109] Olaniran AO, Pillay D, Pillay B. Biostimulation and bioaugmentation enhances aerobic biodegradation of dichloroethenes. Chemosphere 2006; 63 600-608.

[110] Kaplan CW, Kitts CL. Bacterial succession in a petroleum land treatment unit. Applied and Environmental Microbiology 2004; 70 1777-1786.

[111] El Fantroussi S and Agathos SN. Is bioaugmentation a feasible strategy for pollutant removal and site remediation? Current Opinion in Microbiology 2005; 8 268-275.

[112] El Fantroussi S, Belkacemi M, Top EM, Mahillon J, Naveau H, Agathos SN. Bioaugmentation of a soil bioreactor designed for pilot-scale anaerobic bioremediation studies. Environmental Science \& Technology 1999; 33 2992-3001.

[113] Army US. Interim army policy on natural attenuation for environmental restoration: Washington, DC, Department of the Army, Assistant Chief of Staff for Installation Management, DAIM-ED-R (200-1c), September 12, 1995.

[114] EPA (U.S. Environmental Protection Agency). 2001. A Citizen's Guide to Monitored Natural Attenuation. EPA 542-F-01-004, U.S. Environmental Protection Agency, Washington, D.C.

[115] Li CH, Wong YS, Tam NF. Anaerobic biodegradation of polycyclic aromatic hydrocarbons with amendment of iron(III) in mangrove sediment slurry. Bioresource Technology 2010; 101 8083-8092.

[116] Shan HF, Kurtz HD, Freedman D L. Evaluation of strategies for anaerobic bioremediatidon of high concentrations of halomethanes. Water Research 2010; 44 1317-1328.

[117] Bond DR, Lovley DR. Reduction of Fe(III) oxide by methanogens in the presence and absence of extracellular quinines. Environmental Microbiology 2002; 4 115-124.

[118] Chen M., Shih K., Hu M., Li F., Liu C., Wu W. and Tong H. Biostimulation of Indigenous Microbial Communities for Anaerobic transformation of pentachlorophenol in paddy soils of southern China. Journal of Agricultural and Food Chemistry 2012; 60 2967-2975. 
[119] Chen BY., Chen WM. nd Chang JS. Optimal biostimulation strategy for phenol degradation withindigenous rhizobium Ralstonia taiwanensis. Journal of Hazardous Materials; 2007 B139 232-237.

[120] Liliane RR, Meneghetti, AntônioThomé, Fernando Schnaid, Pedro D.M. Prietto and Gabriel Cavelhão. Natural Attenuation and Biostimulation of Biodiesel Contaminated Soils from Southern Brazil with Different Particle Sizes. Journal of Environmental Science and Engineering 2012; B1 155-162.

[121] Fatima M. Bento, Fla'vio A.O. Camargo, Benedict C. Okeke, William T. Frankenberger. Comparative bioremediation of soils contaminated with diesel oil by natural attenuation, biostimulation and bioaugmentation. Bioresource Technology 2005; 96 1049-1055.

[122] Yu KSH, Wong AHY, Yau KWY, Wong YS, Tam NFY. Natural attenuation, biostimulation and bioaugmentation on biodegradation of polycyclic aromatic hydrocarbons (PAHs) in mangrove sediments. Marine Pollution Bulletin 2005; 51(8-12)1071-1077.

[123] Thierry L., Armelle B. and Karine J. Performance of bioaugmentation-assisted phytoextraction applied to metal contaminated soils: A review . Environmental Pollution $2008 ; 153$ 497-522.

[124] Mrozik A, Piotrowska-Seget Z. Bioaugmentation as a strategy for cleaning up of soils contaminated with aromatic compounds. Microbial Research 2006; (2009), doi: 10.1016/j.micres.2009.08.001.

[125] Riser-Roberts E. Remediation of petroleum contaminated soils. Biological, physical, and chemical process. Lewis Publishers Inc (ed). CRC Press LLC. USA. 1998 1-542.

[126] ERD: Environmental Response Division. 1998. Fundamental principles of bioremediation (An aid to the development of bioremediation proposals).

[127] van der Heul RM. Environmental Degradation of petroleum hydrocarbons. 2009

[128] Cases I, de Lorenzo V. Genetically modified organisms for the environment: stories of success and failure and what we have learned from them. International microbiology 2005; 8 213-222.

[129] Sayler GS, Ripp S. Field applications of genetically engineered microorganisms for bioremediation processes. Current Opinion in Biotechnology 2000; 11 286-289.

[130] Ramos JL, Díaz E, Dowling D, de Lorenzo V, Molin S, O'Gara F, Ramos C, Timmis $\mathrm{KN}$. The behavior of bacteria designed for biodegradation. Biotechnology (N Y); 1994 12(13) 1349-56.

[131] Markandey DK and Rajvaidya N. Environmental Biotechnology, 1st edition, APH Publishing corporation 2004; 79. 
[132] Hrywna Y, Tsoi TV, Maltseva OV, Quensen JF, and Tiedje JM. Construction and characterization of two recombinant bacteria that grow on ortho- and para-substituted chlorobiphenyls. Applied and Environmental Microbiology 1999; 65(5) 2163-2169.

[133] Srivastava NK, Jha MK, Mall ID, Singh D. Application of Genetic Engineering for Chromium Removal from Industrial Wastewater. International Journal of Chemical and Biological Engineering 2010; 33.

[134] Xu D and Pei J. Construction and characterization of a photosynthetic bacterium genetically engineered for $\mathrm{Hg}^{2+}$ uptake. Bioresource Technology 2011; 102 3083-3088.

[135] Huang XD, El-Alawi Y, Penrose DM, Glick BR, Greenberg BM. Responses of three grass species to creosote during phytoremediation. Environmental Pollution 2004; 130 453-63.

[136] Sriprang R, Hayashi M, Ono H, Takagi M, Hirata K, Murooka Y. Enhanced accumulation of $\mathrm{Cd}^{2+}$ by a Mesorhizobium sp. transformed with a gene from Arabidopsis thaliana coding for phytochelatin synthase. Applied and Environmental Microbiology 2003; 69: 1791-1796.

[137] Sussman MC, Collins H, Skinner FA, and Stewart-Tull DE (ed.). 1988. Release of genetically-engineered micro-organisms. Academic Press, Inc. (London), Ltd., London.

[138] Wackett LP. Stable isotope probing in biodegradation research. Trends Biotechnol 2004; 22:153-154.

[139] Matin A. Starvation promoters of Escherichia coli. Their function, regulation, and use in bioprocessing and bioremediation. Annals of the New York Academy of Sciences 1994; 721: 277-291.

[140] Pandey G, Paul D, Jain RK. Conceptualizing “suicidal genetically engineered microorganisms" for bioremediation applications. Biochemical and Biophysical Research Communications 2005; 327 637-639.

[141] Iwasaki K, Uchiyama H, Yagi O. Survival and impact of genetically engineered Pseudomonas putida harboring mercury resistance gene in aquatic microcosms. Bioscience Biotechnology \& Biochemistry1993; 57 1264-1269.

[142] Foster L, John R, Kwan Boon N, De Gelder L, Lievens H, Siciliano SD, Top EM, Verstraete W. Bioaugmenting bioreactors for the continuous removal of 3-chloroaniline by a slow release approach. Environmental Science \& Technology 2002; 36 4698-46704.

[143] Ripp S, Nivens DE, Ahn Y, Werner C, Jarrel J, Easter JP, Cox CD, Burlage RS, Sayler GS: Controlled field release of a bioluminescent genetically engineered microorganism for bioremediation process monitoring and control. Environmental Science \& Technology 2000; 34 846-853. 
[144] Singh JS, Abhilash PC, Singh HB, Singh RP, Singh DP. Genetically engineered bacteria: An emerging tool for environmental remediation and future research perspectives. Gene 2011; 480 1-9. 